\title{
Influence of Number of FRP layer on Compressive Behavior of FRP-Confined Lightweight Concrete
}

\author{
Butje A. Louk Fanggi ${ }^{1}$, Melinda R.S. Moata ${ }^{2}$, Ambrosius R.L. Wayan ${ }^{1}$, Abia E. Mata ${ }^{1}$, and \\ Merna Benu ${ }^{1}$ \\ \{butje2017@gmail.com, rosita.moata@gmail.com, ambrosius.wayan@gmail.com, \\ amustakppjj85@gmail.com, merna.benu@gmail.com\} \\ Politeknik Negeri Kupang, Jl. Adi Sucipto, Penfui, Kupang-NTT ${ }^{1}$ \\ Politeknik Pertanian Negeri Kupang, Jl. Prof. Dr. Herman Yohanes, Lasiana, Kupang-NTT ${ }^{2}$
}

\begin{abstract}
This paper presents the results of an experimental study that was undertaken to investigate the effects of the number of FRP layer on the compressive behavior of fiberreinforced polymer-Confined Lightweight Concrete Columns (FCLCs). A total of 6 lightweight concrete were manufactured and tested under axial compression. The results indicate lightweight concrete in a FCLCs system is confined effectively by FRP. The results also suggest that increasing the number of FRP layer leads to an increase in the ultimate axial stress and strain of concrete FCLCs.
\end{abstract}

Keywords: FRP, Lightweight Concrete, Axial Stress, Axial Strain.

\section{Introduction}

Lightweight concrete has advantages that are not possessed by the other concrete (such as normal concrete). The advantages include lightweight, heat resistance, and soundproof. As a result of its lightweight which is $30 \%$ lighter than normal concrete, lightweight concrete is very suitable to be applied in earthquake-prone areas such as Indonesia because of the magnitude of the earthquake load that works on a building/ structure is related to the weight of the building [1], or it can be said that the heavier the building, the higher the earthquake load applied on that building. Thus the application of lightweight concrete as a structural material in Indonesia is one of the solutions to reduce the risk of material loss and casualties due to earthquakes.

However, the use of lightweight concrete is still limited because this concrete has several disadvantages that prevent its application as a structural material which is low compressive strength and low tensile strength [2]. Therefore the application/ use of lightweight concrete is most often found only as a non-structural material.

Fiber Reinforced Polymers (FRP) has been widely recognized as popular materials for the repair or reinforcement of concrete structures. Many studies have been carried out to test the effectiveness of FRP in strengthening / improving the existing concrete structures and the results of these studies have confirmed that the strength and ductility of concrete confined by FRP is significantly improve [3-8]. Therefore FRP can also be used to strengthen the lightweight concrete for structural applications.

However, the research on lightweight concrete reinforced with FRP is very limited, and there are only two tests that can be found in the literature which are conducted by Zhou et al. (2016) [2] and Louk Fanggi et al. (2018) [9]. The studies confirmed that the strength and 
ductility of concrete are significantly improved when FRP is used to strength the concrete. Zhou et al. (2016) [2] conducted the test on lightweight concrete made of ceramsite and steel ring ball as artificial lightweight aggregates (ALWA), and Louk Fanggi et al. (2018) [9] conducted test on lightweight concrete made of pumice as a natural lightweight aggregate. Therefore, consider many various types of ALWA that are available now, further studies are needed to assess the use of FRP for strengthening lightweight concrete made of those types of ALWA such as ALWA from Cilacap which is the only ALWA produced in Indonesia.

\section{Experimental Program}

\subsection{Test Specimens and Materials}

A total of 6 lightweight concrete specimens were confined with FRP that were fabricated using Carbon fibers were prepared and tested under concentric compression. The specimens had a diameter of $100 \mathrm{~mm}$, measured at the concrete core, and a height of $200 \mathrm{~mm}$. Two nominally identical specimens were tested for each unique specimen configuration. Details of the specimens are shown in Table 1.

Table 1. Details of test specimens.

\begin{tabular}{|c|c|c|c|c|}
\hline Specimen & $f_{\text {со }}^{\prime}(\mathrm{MPa})$ & $\varepsilon_{\mathrm{co}(\%)}$ & Number of FRP layer & Number of Specimen \\
\hline FCLC1-1 & \multirow{6}{*}{18,26} & \multirow{6}{*}{0,16} & 1 & 1 \\
\hline FCLC1-2 & & & 1 & 1 \\
\hline FCLC2-1 & & & 2 & 1 \\
\hline FCLC2-2 & & & 2 & 1 \\
\hline FCLC3-1 & & & 3 & 1 \\
\hline FCLC3-2 & & & 3 & 1 \\
\hline
\end{tabular}

All specimens were prepared using a single mix with $18.26 \mathrm{MPa}$ average unconfined concrete compressive strengths that were attained at the time of testing. The mix consisted of ALWA as the coarse aggregate, with a nominal maximum size of $10 \mathrm{~mm}$. The average unconfined concrete strengths ( $\left.f^{\prime} c\right)$ attained during the period of testing are shown in Table 1 . It should be noted that the $\varepsilon_{\text {co }}$ is not measured directly from the control specimens but it is calculated by using the equation provided by Tasdemir [11]. The specimens were wrapped with 1, 2, and 3 layers of carbon fiber sheets, with nominal ply thickness of $0.129 \mathrm{~mm}$ and ultimate tensile strength of $3850 \mathrm{MPa}$.

\subsection{Testing Procedures}

The specimens were tested under axial compression using a $1000-\mathrm{kN}$ servo-hydraulic universal testing machine. Displacement control was used at approximately $0.003 \mathrm{~mm}$ per second until all specimens failure. Before testing, a capping process was completed at one end of all specimens to ensure uniform distribution of the applied pressure. 


\section{Test Results}

\subsection{Observed Failure Modes}

All specimens failed due to rupture of FRP in the hoop direction. It was observed that the rupture of FRP of FCLC1-1\&2 were observed to experience more extensive compared to FCLC2 and FCLC3, which were initiated at the mid-height and extended towards the top and bottom of the specimens as illustrated in Fig. 1a, on the other hand, FCLC3 exhibited localized FRP ruptures (Fig. 1d) without a similar explosive failure that was observed in FCLC1 and FCLC2.

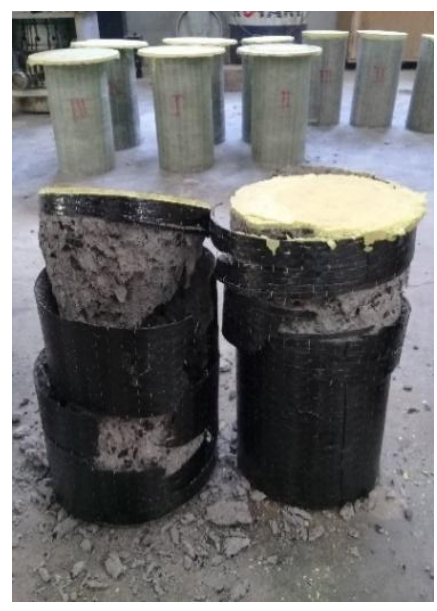

a) FCLC1-1\&2

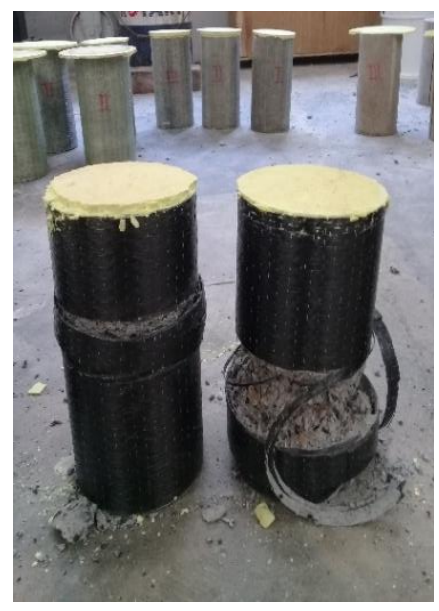

b) FCLC2-1\&2

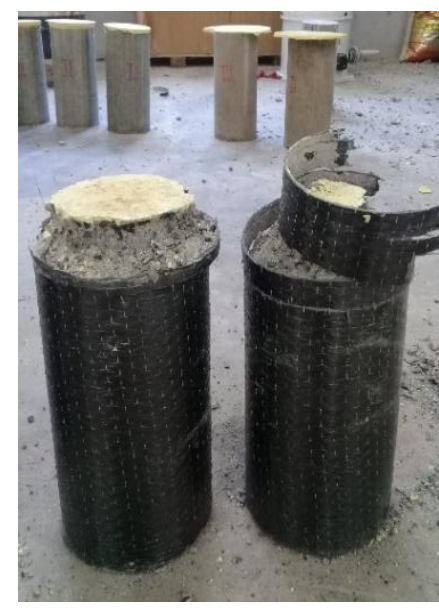

FCLC3-1\&2

Fig. 1. Failure Modes

\subsection{Axial Stress-Strain Behavior}

Figure 2 present the concrete stress-strain relationships for all specimens. It can be seen that all the specimens exhibited almost monotonically ascending stress-strain curves, indicating that the concrete inside them was efficiently confined.

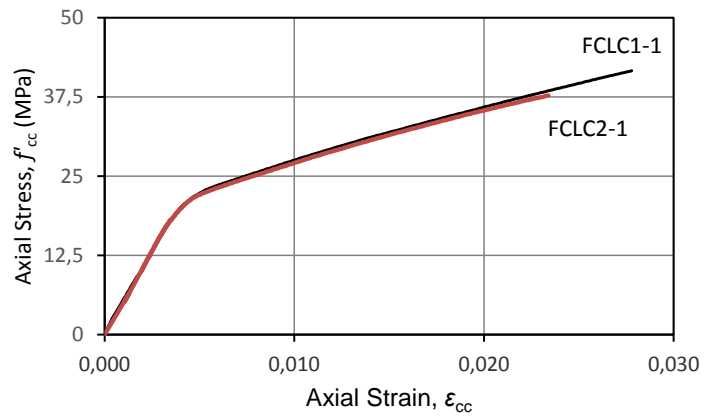

a) $\mathrm{FCLC} 1-1 \& 2$

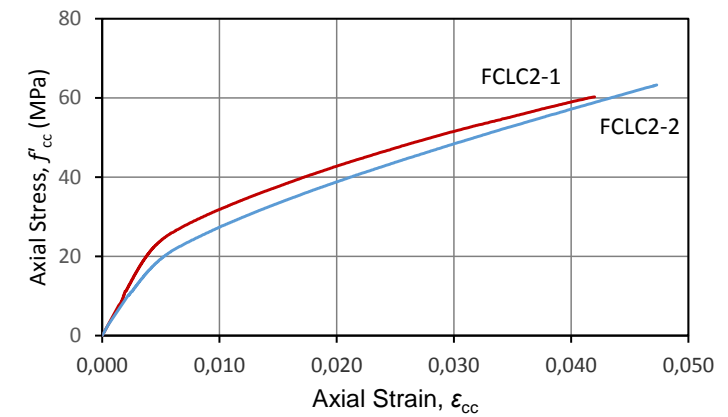

b) FCLC2-1\&2 


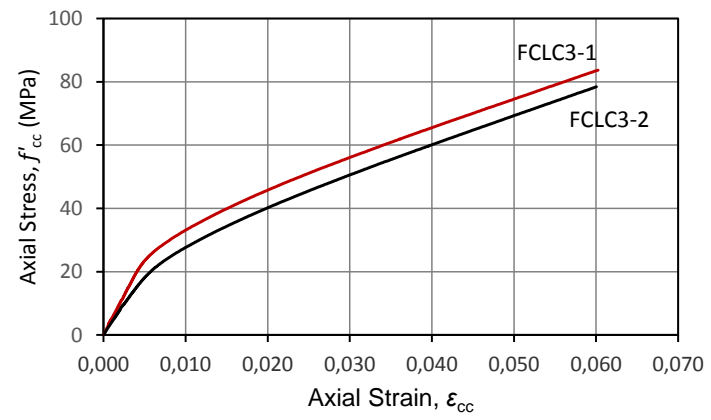

c) FCLC3-1\&2

Fig. 2. Stress-strain behavior of FCLCs

\subsection{Influence of Number of FRP Layers}

Figure 3 presents the stress-strain relationships of the specimens with different number of FRP layer. It can be seen that the FCLC with a higher number of FRP layer experienced higher ultimate stress $\left(f^{\prime}{ }^{\prime}\right)$ and strain $\left(\varepsilon_{\mathrm{cu}}\right)$ compared to specimens with lower number of FRP layer.

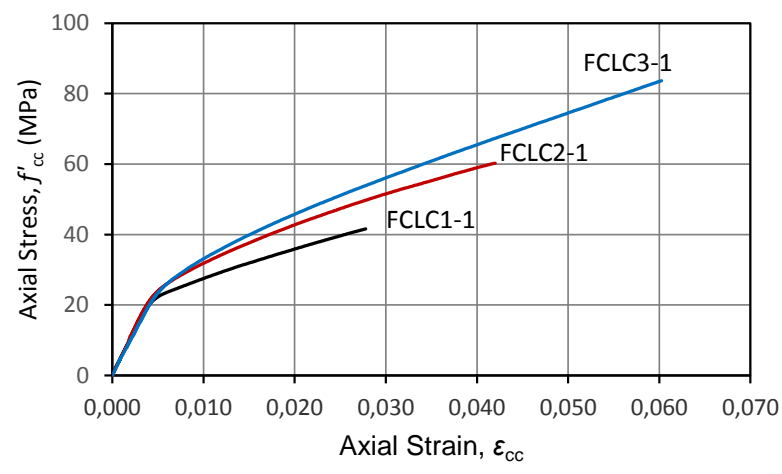

Fig. 3. Influence of Number of FRP Layer.

The above observation is also supported by the one that can be made from the comparison of the average value of $f^{\prime}$ cu and $\varepsilon_{\mathrm{cu}}$ reported in Table 2. 
Table 2. Compressive behavior of FCLCs.

\begin{tabular}{lcccccc}
\hline Specimen & $\begin{array}{c}f_{\text {cu }}^{\prime} \\
(\mathrm{MPa})\end{array}$ & Ave. $f^{\prime}{ }_{\mathrm{cu}}(\mathrm{MPa})$ & $\begin{array}{c}\text { Ave. } f_{\mathrm{cu}}^{\prime} / \\
f_{\mathrm{c}}^{\prime}\end{array}$ & $\begin{array}{c}\varepsilon_{\mathrm{cu}} \\
(\%)\end{array}$ & Ave. $\varepsilon_{\mathrm{cu}}(\%)$ & Ave. $\varepsilon_{\mathrm{cu}} / \varepsilon_{\mathrm{co}}$ \\
\hline FCLC1-1 & 41,63 & 39,68 & 2,17 & 2,78 & 2,56 & 16,02 \\
FCLC1-2 & 37,72 & & & 2,34 & & \\
FCLC2-1 & 60,25 & \multirow{2}{*}{61,76} & 3,38 & 4,20 & 4,47 & 27,94 \\
FCLC2-2 & 63,26 & & & 4,73 & & \\
FCLC3-1 & 83,69 & \multirow{2}{*}{81,07} & 4,44 & 6,03 & 6,02 & 37,68 \\
FCLC3-2 & 78,44 & & & 6,01 & & \\
\hline
\end{tabular}

\section{Conclusions}

This paper has presented the current results from an ongoing experimental study on the axial compressive behavior of FRP-confined lighweight concrete. Based on the test results presented in this paper, the following conclusions can be drawn:

1. FCLCs demonstrates monotonically ascending stress-strain curve, indicating that the lighweight concrete is confined effectively by FRP.

2. Increasing the number of FRP layer leads to an increase in the ultimate axial strength $\left(f^{\prime}{ }^{\prime}\right)$ and strain $\left(\varepsilon_{\mathrm{cu}}\right)$ of FCLCs.

\section{Acknowledgments}

The work presented in this paper has received financial support from Politeknik Negeri Kupang. The authors are grateful to Politeknik Negeri Kupang for the financial support.

\section{References}

[1] P. Risdanareni, A. A. Choiri, B. Djatmika, and P. Puspitasari, "Effect of the Use of Metakaolin Artificial Lightweight Aggregate on the Properties of Structural Lightweight Concrete," Civ. Eng. Dimens., vol. 19, no. 2, pp. 86-92, 2017.

[2] Y. Zhou, X. Liu, F. Xing, H. Cui, and L. Sui, “Axial compressive behavior of FRPconfined lightweight aggregate concrete: An experimental study and stress-strain relation model," Constr. Build. Mater., vol. 119, pp. 1-15, 2016.

[3] Stanton JF, Owen LM. (2006), The influence of concrete strength and confinement type on the response of FRP-confined concrete cylinders, vol. 238. ACI Special Publication; October p. 347-62.

[4] Tamuzs V, Tepfers R, Zile E, Ladnova O. (2006), Behavior of concrete cylinders confined by a carbon composite III: deformability and the ultimate axial strain. Mech Compos Mater 42(4):303-14.

[5] Wu G, Lu ZT, Wu ZS. (2006), Strength and ductility of concrete cylinders confined with FRP composites. Constr Build Mater 20(3):134-48. 
[6] Almusallam, T. H. (2007), Behaviour of normal and high-strength concrete cylinders confined with e-glass/epoxy composite laminates. Compos. Part B, 38(5-6), 629-639.

[7] Cui C, Sheikh A. (2010), Experimental study of normal- and high-strength concrete confined with fiber-reinforced polymers. ASCE J Compos Constr 14(5):553-61.

[8] Vincent T, Ozbakkaloglu T. (2013), Influence of fiber orientation and specimen end condition on axial compressive behavior of FRP-confined concrete. Constr Build Mater 47:814-26.

[9] Vincent T, Ozbakkaloglu T. (2013), Influence of concrete strength and confinement method on axial compressive behavior of FRP confined high- and ultrahigh strength concrete. Compos Part B-Eng 50:413-28.

[10] Louk Fanggi, B A, Muda A H, Mata A E, Umbu Nday A A, Bria M, dan Wayan R L. (2018), Kuat Tekan Kolom Beton Ringan yang Diperkuat dengan Carbon Fiber Reinforced Polymer. Jurnal Teknik Sipil, [S.1.], 3.(1):259-265.

[11] Tasdemir, M. A., Tasdemir, C., Jefferson, A. D., Lydon, F. D., and Barr, B.I. G. (1998). "Evaluation of strains at peak stresses in concrete: A threephase composite model approach.” Cement Concr. Res., 20(4), 301-318. 